\title{
TINJAUAN KRITIS TERHADAP EPISTEMOLOGI IMMANUEL KANT (1724-1804)
}

\section{Lailiy Muthmainnah}

Fakultas Filsafat Universitas Gadjah Mada

Email: lailiy@ugm.ac.id

\section{Abstrak}

Latar belakang artikel ini adalah problem metafisika yang muncul dalam pemikiran Immanuel Kant dalam karyanya Critique of Pure Reason. Melalui pendekatan hermeneutik artikel ini bertujuan untuk menganalisis problem metafisika yang muncul dalam pemikiran epistemologi Immanuel Kant. Berdasarkan hasil penelitian dapat disimpulkan bahwa pemisahan secara tegas antara fenomena dan noumena akan menyebabkan manusia tidak akan pernah sampai pada pengetahuan yang Transenden, begitupun dengan moral dan estetika. Hal ini disebabkan karena pengetahuan tersebut hanya dapat diperoleh dengan melalui partisipasiku sebagai Subjek melalui proses eksistensi secara terus menerus dan lebih merupakan undangan pribadi. Pada akhirnya dapat disimpulkan bahwa sifat pengetahuan yang analog merupakan pemaknaan atas multidimensionalitas kehidupan manusia. Hal ini membawa konsekuensi pada perlunya dialog intersubjektif dan keterbukaan secara terus menerus. Pengetahuan adalah sesuatu hal yang tidak berbatas, pengetahuan manusia karenanya tidak akan pernah sampai pada ujung perjalanan melainkan hanya terus menerus diperluas cakrawalanya.

Kata kunci: Immanuel Kant, epistemologi, fenomena, noumena, analog.

\section{Abstract}

The background of this article is a metaphysical problem that arose in Immanuel Kant's thought in his Critique of Pure Reason. Through a hermeneutic approach this article aims to analyze the metaphysical problems that arise in Immanuel Kant's epistemology of thought. Based on the research results can be concluded that the unequivocal separation between phenomena 
and noumena will cause humans will never come to the knowledge of the Transcendent, as well as with moral and aesthetics. This is because such knowledge can only be obtained through my participation as a Subject through the process of continuous existence and more of a personal invitation. In the end it can be concluded that the nature of analog knowledge is the meaning of multidimensional side of human life. This brings consequences to the need for intersubjective dialogue and continual openness. Knowledge is an infinite thing. Human knowledge therefore will never reach the end of the journey but only continuously expanded its horizon.

Keywords: Immanuel Kant, epistemology, phenomenon, noumena, analog.

\section{PENDAHULUAN}

"Epistemology or the theory of knowledge is that branch of philosophy which is concerned with the nature and scope of knowledge, its presuppositions and basis, and in the general realibility of claims to knowledge." (Hamlyn, 1967:8).

Epistemologi atau teori pengetahuan adalah cabang filsafat yang berkaitan dengan hakikat dan ruang lingkup pengetahuan, dasar dan pengandaian-pengandaiannya, serta secara umum berkaitan dengan hal dapat diandalkannya penegasan bahwa orang memiliki pengetahuan.

Pada awalnya manusia percaya bahwa dengan kemampuan pengenalannya manusia mampu mencapai realitas sebagaimana adanya. Filsuf-filsuf pra-Sokrates misalnya menerima begitu saja bahwa manusia dapat mengenal hakikat benda (nature), meskipun terkait mekanisme pengenalan ada yang lebih menekankan peran indra (Heraclitus), tetapi ada juga yang menentang karena lebih menekankan pada akal (Parmenides). Meskipun demikian, keduanya percaya bahwa pengenalan manusia hingga mencapai pemahaman atas realitas sebagaimana adanya adalah sesuatu hal yang mungkin (Hamlyn, 1967: 9).

Keraguan atas hal tersebut di atas baru muncul sekitar abad ke-5 SM, yang terutama dipelopori oleh kaum Sophis. Kaum Sophis menegaskan bahwa setiap orang harusnya mengukur hal ikhwal 
menurut hakikat dan kepentingannya sendiri, sebab hanya manusialah ukuran segala hal ikhwal. Skeptisisme ala kaum Sophis ini menyebabkan timbulnya epistemologi seperti yang secara tradisional dimaknai sebagai usaha untuk mencari pembenaran atas pernyataan bahwa pengetahuan itu mungkin serta untuk menilai bagaimana peranan indra dan akal dalam pengenalan. Perkembangan epistemologi semakin nampak ketika Plato mulai memunculkan pertanyaan-pertanyaan dasar tentang: Apa pengetahuan? Dimana pengetahuan biasanya diperoleh? Di antara apa yang biasa dianggap diketahui oleh manusia berapa persen yang sungguh-sungguh merupakan pengetahuan? Dapatkah indra menghasilkan pengetahuan? Dapatkan akal memberikan pengetahuan? Apakah hubungan antara pengetahuan dan kepercayaan yang benar? (Taryadi, 1988: 18)

Pada sejarah perkembangan epistemologi, pertanyaanpertanyaan pokok tersebut di atas telah menimbulkan berbagai macam jawaban yang saling berlainan. Diantara berbagai macam aliran yang mencoba menyusun teori pengetahuan, ada dua aliran besar yang sangat berpengaruh kuat, yaitu rasionalisme dan empirisme. Pertentangan dua aliran besar inilah yang kemudian membentuk gagasan pengetahuan Immanuel Kant yang dijadikan sebagai pusat kajian dalam artikel ini. Pemilihan tokoh Immanuel Kant (1724-1804) lebih didasarkan pada argumentasi bahwa tokoh ini memiliki posisi yang sangat sentral dalam tahap perkembangan epistemologi Barat, khususnya dalam upaya menjembatani konflik antara empirisme dan rasionalisme. Oleh karena itu kajian tentang Immanuel Kant dalam ranah epistemologi tetap akan menempati posisi yang penting.

\section{PEMBAHASAN}

\section{Sekilas tentang Immuel Kant}

Immanuel Kant lahir pada tanggal 22 April 1724 di Konigsberg (dulu adalah ibukota propinsi Jerman), Prusia Timur. Nenek moyang Immanuel Kant berasal dari Skotlandia yang berimigrasi pada abad sebelumnya. Pada saat Immanuel Kant lahir, Prusia Timur sedang berada pada fase pemulihan kondisi dari 
kehancuran yang disebabkan karena perang dan munculnya wabah penyakit. Akibat dari perang dan bencana yang melanda tersebut, Prusia timur kehilangan hampir separuh dari total penduduknya.

Terlahir sebagai anak keempat dari enam bersaudara, Immanuel Kant dibesarkan dalam sebuah situasi kemiskinan. Ayahnya berdarah Skotlandia, sedangkan ibunya berdarah Jerman. Ayah Kant bekerja sebagai seorang tukang potong tali kulit, sedangkan ibunya adalah seorang perempuan yang tidak mendapatkan pendidikan formal namun memiliki "kecerdasan alamiah" yang luar biasa. Kecerdasan inilah yang turun dalam diri Immanuel Kant.

Pada usia 18 tahun, Immanuel Kant memasuki Universitas Konigsberg sebagai mahasiswa teologi. Namun tidak lama setelah itu, minatnya lebih banyak tertuju pada matematika dan fisika. Kant banyak membaca karya-karya Newton yang kemudian memberikan inspirasi baginya terkait berbagai kemajuan dalam ilmu pengetahuan. Pada tahun 1746, ketika Kant berusia 22 tahun, ayahnya meninggal dunia sehingga ia terpaksa meninggalkan universitas untuk mencari nafkah. Meski kemudian tahun 1755 ia dapat menyelesaikan studinya dan menjadi pengajar diuniversitas tersebut. Kembalinya Kant ke Universitas Konigsberg tersebut ditandai dengan diterbitkannya buku Kant yang berjudul General Natural History and Theory of Heavens. Pada karyanya ini Kant membahas hipotesis bahwa sistem tata surya bersumber dari nebulus sebagai materi asali (https://plato.stanford.edu/entries/kant/).

Sepanjang perjalanan karir inteletualnya, Kant tidak hanya tertarik pada fisika Newton, tetapi juga filsafat Leibniz dan Wolf. Selain itu, Kant adalah seorang Kristiani yang taat. Pada sebuah buku disebutkan bahwa Kant adalah seorang ilmuwan, filsuf, dan juga theolog. Sehingga tidak mustahil perkembangan pemikiran Kant dipengaruhi oleh tiga hal tersebut. Melalui epistemologinya, Kant mencoba untuk menyusun sebuah sistem yang mampu mendasari, menyatukan, dan menjelaskan semuanya. Gagasannya ini kemudian dituangkan dalam karyanya yang berjudul Critique of Pure Reason, yang menjadi penanda dimulainya era kritik modern. Pada karyanya 
tersebut nampak secara jelas bagaimana Kant terdorong untuk menemukan kepastian-kepastian dasar yang mendasari pengetahuan sehingga dapat dikembang pada sebuah penataan epistemologis. Perjalanan panjang Kant untuk sampai pada fase kritisnya tersebut terlebih dahulu dimulai dengan keterlibatannya dengan masalahmasalah filsafat seperti masalah kausalitas, pengetahuan, sensibilitas dan intelligibilitas, dan juga mengenai adanya Tuhan. Hal ini setidaknya memang banyak dipengaruhi karena secara faktual Kant merupakan seorang tenaga pengajar pada bidang Logika dan Metafisika di Universitas Konigsberg. Namun pada akhirnya pure reason serta problem das Ding an Sich (noumenon) menjadi tema pokok yang dikaji oleh Immanuel Kant yang dipandang paling monumental (Pranarka, 1987: 137).

Immanuel Kant berhenti mengajar dari Universitas Konigsberg pada tahun 1797 karena mulai sakit-sakitan. Setelah itu Kant mulai memfokuskan pada kegiatan untuk mengedit kembali karya-karyanya. Sampai akhirnya Kant meninggal dunia pada 12 Februari 1804 dan dimakamkan di Katedral Konigsberg https://plato.stanford.edu/entries/kant/.

Immanuel Kant wafat dengan meninggalkan sejumlah karya, diantaranya adalah :

a. General History of Nature and Theory of the Heavens;

b. On the Form and The principles of the Sensible and Intelligible World;

c. Critique of Pure Reason;

d. Critique of Practical Reason;

e. Critique of Judgment;

f. Religion within the Bound of Mere Reason;

g. Metaphysics of Moral.

Dari sekian banyak karyanya tersebut, ada tiga karya yang dipandang sangat monumental, yaitu Critique of Pure Reason, Critique of Practical Reason, dan Critique of Judgement.

\section{Epistemologi Immanuel Kant}

1. Latar belakang : pertentangan rasionalisme dan empirisme

Epistemologi Immanuel Kant tidak pernah dapat dilepaskan 
dari keberadaan dua aliran besar tentang pengetahuan yaitu rasionalisme dan empirisme. Teori pengetahuan yang dikembangkan oleh Plato dan Descartes yang disebut dengan "rasionalisme" menegaskan bahwa pengetahuan hanya akan ditemukan dengan menggunakan akal. Rasionalisme memiliki asumsi bahwa pengetahuan yang pasti secara mutlak tidak akan pernah dicapai melalui pengalaman inderawi melainkan harus dicari dalam alam pikiran (in the realm of the mind) (Richard H. Popkin dalam Taryadi, 1989:19).

Descartes sebagai tokoh sentral dalam rasionalisme menyebutkan bahwa persepsi inderawi merupakan suatu penampakan yang pucat dan tidak lengkap dari kenyataan. Gagasan ini selaras dengan apa yang dikemukakan oleh Plato pada fase jauh sebelumnya. Objektivitas dari hal yang ditangkap melalui indra sangat kabur. Bahkan Descartes mengibaratkan hal tersebut dengan mimpi yang terpotong dari kenyataan lepas. Hal ini dikarenakan menurut kalangan rasionalis kesadaran manusia akan yang lain merupakan hasil kerja pikiran (Hadi, 1994:42).

Sebagai reaksi terhadap rasionalisme, maka muncullah empirisme. Diantara filsuf yang dapat digolongkan dalam aliran empirisme ini adalah John Locke, Berkeley, dan David Hume. Secara umum filsuf-filsuf empiris mencoba untuk menemukan basis pengetahuan pada pengalaman inderawi. John Locke sebagai bapak empirisme berpendapat bahwa semua inteligibilitas ditarik dari indra. Budi manusia pada saat lahir adalah tabula rasa, ibarat papan kosong yang belum ditulisi apapun. Seluruh isi pikiran pada akhirnya dapat direduksikan pada pengalaman inderawi (sensasi dan refleksi). Kesan-kesan inderawilah yang melukiskan isi pikiran. Dari lukisan itu kemudian budi bekerja membangun pemahaman. Sebagai seorang idealis epistemologis Locke berkesimpulan bahwa setiap tindakan mengetahui akan berakhir pada ide yang murni subjektif. Kenyataan pada akhirnya adalah bentuk geometris dan kesan subjektif, substansi material sendiri tidak pernah terjangkau, " $X$ " yang tersembunyi.

George Berkeley seorang realis epistemologis memberikan kritik terhadap pemikiran John Locke. Menurut Berkeley, pengalaman 
identik dengan ide dan bersifat spiritual. Hal ini disebabkan karena semua kenyataan dialami dalam budi sehingga bersifat spiritual. Kesadaranlah yang menghubungkan saya dengan yang lain, sehingga tidak ada kualitas primer dan sekunder, yang ada hanyalah kualitas saja. Tidak ada " $X$ " yang tersembunyi. "Esse est aut percipere aut percipi", ada berarti dipersepsi atau mempersepsi. Saya ada dan objek dari pengalaman saya juga ada. Hal ini yang memberikan pendasaran bagi adanya budi Absolut yang setiap saat mempersepsi data yang saya persepsi tatkala budi terbatas yang mempersepsi mereka tidak ada. Sensasi yang berdikari ini menjadi bukti bagi adanya Allah.

Meskipun demikian pemikiran Berkeley juga memunculkan persoalan yaitu tentang ketidak jelasan ide milik siapa yang disadari oleh Aku. Apakah ide saya sendiri ataukah Ide dari Allah. Jika ide itu adalah ide saya sendiri maka mungkinkah dengan kesadaran subjektif saya mampu mengatasi diri sendiri? Bahkan Allah juga sekedar menjadi ide subjektif saya? Tetapi jika ide itu adalah ide dari Allah, maka saya dapat meyakini sesuatu itu tetap ada karena Allah telah mencetakkan ide itu kepada saya secara mental. Argumentasi ini nampaknya agak tidak konsisten dengan gagasan realisme Berkeley, melainkan lebih condong ke arah idealis.

Tokoh empiris selanjutnya yaitu David Hume, yang secara konsisten menempatkan sumber pengetahuan pada pengamatan. Melalui pengamatan maka akan diperoleh kesan-kesan (impressions) dan gagasan/pengertian (ideas). Jika kesan-kesan merupakan pengamatan langsung yang diterima dari pengalaman baik lahiriah maupun batiniah yang menampak dengan jelas, hidup, dan kuat, sehingga sangat memadai. Maka gagasan/pengertian merupakan gambaran tentang pengamatan yang redup, merenungkan kembali atau merefleksikan dalam kesadaran kesan-kesan yang telah diterima dari pengalaman. Gagasan hanyalah tembusan (copy) dari kesankesan, sebab tidak semua dapat dihadirkan dalam pikiran lagi.

David Hume sangat setia pada epistemologi inderawi, dan menolak adanya sebab atau kausalitas. Menurut Hume, yang diamati oleh manusia sesungguhnya hanyalah urutan peristiwa dan bukanlah suatu keniscayaan. Pemahaman tentang keniscayaan itu muncul karena kebiasaan yang dikembangkan oleh manusia sendiri, bahwa 
ketika peristiwa A terjadi maka pasti akan terjadi peristiwa B. Sehingga ketika suatu saat terjadi peristiwa B maka umumnya seseorang akan menghubungkannya dengan adanya peristiwa A yang mendahuluinya. Hal yang semacam ini menurut Hume hanyalah keniscayaan subjektif pada diri individu tersebut, dan bukan sebagai kenyataan objektif dari bendanya. Keniscayaan subjektif tersebut kemudian dimasukkan dalam urutan objektif dan diperlakukan sebagai hubungan yang tidak terelakkan di dalam peristiwa-peristiwa. Hal ini menurut Hume dapat dipahami secara psikologis, namun tidak dapat dibenarkan secara logis. Sehingga ketika terjadi sebuah peristiwa maka hal itu murni sebagai sebuah peristiwa fisik belaka, sehingga tidak ada yang tidak masuk akal ketika terjadi sesuatu yang berbeda dari yang biasanya terjadi. Atas dasar inilah David Hume menolak kausalitas, karena hal tersebut dianggap sebagai kategori yang subjektif saja, bukan keabsahan objektif (Hadi, 1994: 100). Apa yang dianggap sebagai pengetahuan oleh manusia ternyata tak lain hanyalah suatu cara mengatur pengalaman yang tersodor kepada manusia. Hukum alam yang seolah valid untuk semua hal, sekarang maupun masa depan ternyata bagi Hume sesungguhnya tidak mampu memberikan jaminan absolut tersebut.

Pemikiran John Locke, Berkeley, maupun Hume tersebut di atas ternyata memberikan pengaruh yang sangat besar dalam sejarah perkembangan epistemologi Barat. Tidak hanya dalam hal penyempurnaan teori empiris pengetahuan saja melainkan juga mulai muncul upaya-upaya untuk menjembatani problem pengetahuan yang muncul dari dua teori besar, rasionalis dan empiris.

\section{Kritisisme Kant}

Epistemologi Immanuel Kant dapat diposisikan sebagai jembatan antara rasionalisme dan empirisme. Baik rasionalisme maupun empirisme mencoba untuk menjawab persoalan: "nilai apa yang ada dalam pengetahuan yang saya peroleh mengenai dunia fisik (material) dan kaitannya dengan apa yang harus saya lakukan?" Pandangan rasionalisme memulainya dengan asumsi bahwa 
kepastian/pengetahuan hanya dapat diperoleh melalui kerja pikiran karena dalam pikiran manusia telah ada ide-ide bawaan yang bersifat universal. Sifat universal ini dibutuhkan dalam pengetahuan ilmiah maupun filsafat, tetapi sayangnya rasionalisme gagal untuk menjelaskan keabsahan pengetahuan tersebut dalam rujukannya kepada dunia alam tanpa terjatuh pada panteisme.

Sementara itu empirisme dalam menjawab pertanyaan yang sama tersebut di atas, memulainya dengan proses persepsi inderawi. Empirisme mengklaim bahwa melalui persepsi inderawi akan diperoleh gambaran atas objek sebagaimana adanya. Namun empirisme melupakan bahwa dalam setiap persepsi inderawi tetap saja bersifat partikular bukan universal. Kegagalan rasionalisme maupun empirisme inilah yang menjadi latar belakang utama epistemologi Immanuel Kant. Beliau dengan kritisismenya mencoba untuk menjembatani pertentangan antara rasionalisme dan empirisme dan menjadi "fenomenalisme baru".

Pemikiran epistemologi Kant pada karyanya yang berjudul Critique of Pure Reason dimulai dengan penjelasan atas perbedaan sifat pengetahuan yang bercorak analisis-sintesis dan apriori-aposteriori.

Kant menyatakan bahwa rasionalisme memiliki sifat analitikapriori (mendahului pengalaman). Adapun ciri putusan yang bersifat analitik apriori adalah mengkonstruksi sebuah sistem pengetahuan yang dilengkapi dengan dimensi universalitas atau keniscayaan. Hanya saja, jenis pengetahuan yang semacam ini bersifat tautologis, hanya pengulangan dan kurang andal, karena tidak menyajikan sesuatu yang baru. Sedangkan empirisme memiliki sifat sintesisaposteriori. Kebenaran sintetik adalah kebenaran bersyarat, tergantung pada bagaimana dunia sebagaimana adanya (aposteriori setelah pengalaman). Keunggulan dari jenis putusan yang bersifat sintesis-aposteriori adalah mampu memberikan pengetahuan baru. Namun kelemahannya adalah predikat tidak lebih dari fakta pengalaman, sehingga model putusan yang semacam ini akan kehilangan aspek universalitasnya.

Menurut Kant, ada satu lagi jenis putusan yaitu sintesisapriori. Jenis putusan ini akan memiliki ciri universalitas dengan tanpa bersifat tautologis. Adapun syarat pembentukan putusan sintesis 
apriori adalah harus memiliki forma dan materi. "Forma" diperoleh dari intelek yang bersifat independen dari semua pengalaman, bersifat apriori, menandakan fungsi-cara-dan-hukum mengetahui dan bertindak yang eksistensinya mendahului pengalaman. Sedangkan "materi" adalah sensasi subjektif yang diterima dari luar. Forma dalam hal ini mewakili aspek universalitas dan niscaya, sedangkan materi mewakili data empiris. Sehingga jenis putusan yang sintesisapriori akan bersifat universal dan niscaya dengan tetap absah dalam dunia empiris.

\section{Revolusi kopernikan}

Untuk dapat sampai pada kebenaran yang sintetik apriori maka harus terjadi revolusi pikiran dari proposisi-proposisi. Revolusi Kopernikan yang muncul pada epistemologi Kant ini mencoba untuk menjawab pertanyaan : apa yang dapat kita ketahui; apa yang harus kita kerjakan; serta apa yang harus dipercaya, menemukan pembenarannya bukan dalam realitas yang ada dalam dirinya sendiri (noumenon) sebagaimana metafisika tradisional memahaminya, melainkan dalam kemampuan teoritis, praktis, dan estetis manusia (Asdi, 1995: 10-11). Hal ini sesungguhnya dilakukan untuk mengetahui dasar kepastian tentang daya pengetahuan.

Sebagaimana halnya revolusi Kopernikan yang mengubah semuanya, bahwa pusat tata surya adalah matahari, bukan bumi, maka revolusi Kant dalam epistemologi menempatkan materi-materi pikiran yang ada pada Subjek sebagai pusat pemahaman atas dunia empiris, bukan materi-materi objek. Artinya, jika pada masa sebelumnya pengamatan berfokus pada objeknya, maka Kant meletakkan basis epistemologinya dengan mengatakan bahwa objeklah yang mengarahkan diri pada subjek. Kant tidak memulai dari Objek yang ada tetapi dari yang terdekat lebih dahulu, yaitu pengamat objek, dengan kata lain "subjek". Seluruh pengetahuan hanya dalam kegiatan subjek, bahkan intelek semata-mata. Oleh karena itu Kant memisahkan antara noumenon (das Ding an Sich) dengan fenomenon (objek sebagai yang berada dalam pikiran, produk dari proses intelektual di dalam diri subjek). 
Melalui revolusi epistemologi yang Kant lakukan, ia memposisikan pikiran sebagai sesuatu yang aktif, tidak pasif. Pikiran tidak melulu mencerminkan dunia, melainkan dalam aktivitas tertentu pikiran mampu membangun dunia. Untuk mengetahui dunia pengalaman, bukan pikiran yang menyesuaikan dunia, tetapi dunia yang harus menyesuaikan pikiran. Pikiran akan membentuk dan mengkategorikan objek secara aktif, mengubah dunia objek dalam ruang dan waktu, terletak dalam relasi sebab-akibat, dan menaati aturan lain. Pikiran menyaratkan struktur sehingga dunia pengalaman dapat diketahui.

Ruang dan waktu merupakan bentuk intuisi inderawi, yang sekaligus menunjukkan adanya aktivitas pikiran yang menstruktur. Manusia dapat mengalami sebuah dunia objek-objek karena ia terletak di dalam ruang, serta dapat selalu berubah karena ruang dan waktu adalah bentuk-bentuk subjektif inderawi. Artinya segala yang dialami oleh manusia harus melalui proses sensasi/pengindraan dalam lensa ruang dan waktu.

Lebih lanjut Kant berpendapat bahwa intuisi-intuisi inderawi tidaklah cukup untuk mengetahui. Intuisi inderawi tersebut harus dibawa pada konsep-konsep yang dibentuk dan diatur oleh 12 kategori, yaitu : kesatuan, pluralitas, totalitas, kenyataan, negasi, pembatasan, substansi, sebab akibat, kesalingan, kemungkinan, aktualitas, dan kebutuhan. Adanya kategori ini membuktikan bahwa dunia yang kita alami adalah dibentuk oleh pemikiran. Proses inilah yang disebut dengan deduksi transendental.

Adapun satu-satunya jalan untuk membuktikan validitas kategori-kategori tersebut adalah dengan menunjukkan bahwa kategori-kategori tersebut dijamin dalam segala kemungkinan pengalaman. Esensi deduksi tersebut adalah sebagai berikut: pengalaman subjektif yang yang dimiliki subjek hanya mungkin jika ada dunia objektif. Pada poin ini Kant hendak menunjukkan bahwa prinsip kausalitas/sebab dapat diterapkan pada kenyataan objektif. Dengan adanya konsep sebab maka dapat dibedakan antara kenyataan objektif dan subjektif. Pengalaman muncul dari sensasi, sehingga indra disini tidak memberikan objek, karena bahan mentah dari sensasi tersebut adalah kategori-kategori formal akal. Semua 
sensasi akan disajikan dalam urutan waktu. Semua sensasi mengalir beberapa mengalir dalam tata aturan niscaya dan beberapa lainnya tanpa aturan. Inilah yang membedakan antara subjektif dan objektif. Wahana yang objektif adalah wahana dari fenomen yang teratur.

Selanjutnya saya sadar sebagai "subjek" yang membedakan diri dari penonton pada wahana yang teratur tadi. Pengalaman yang kacau tidak akan memberikan dasar untuk membedakan antara subjek dan objek. Oleh karena itu kategori sebab/kausalitas merupakan hal yang niscaya dalam peristiwa-peristiwa. Keabsahan sebab hanya terkait fenomen. Hal ini dikarenakan objek hanya akan tampil sejauh dalam fenomen, sedangkan objeknya sendiri (noumena) tidak akan terjangkau. "Sebab" adalah hubungan teratur antarfenomena.

Subjek hanya dapat menangkap objek sejauh dalam fenomen. Hal ini dikarenakan noumena (das Ding an Sich) tidak akan pernah terjangkau. Kategori-kategori formal akal hanya berlaku sejauh masih dalam jangkauan ruang dan waktu. Jika coba dibandingkan dengan pemikiran John Locke tentang kualitas primer dan kualitas sekunder, maka bagi Kant tidak ada pembedaan antara dua kualitas tersebut karena keduanya sama tampil sebagai fenomen. Kategori-kategori formal akal tersebut tidak akan berlaku untuk hal-hal yang metafisik, karena hal tersebut masuk pada area noumena. Jika tetap digunakan maka hal itu merupakan bentuk pemaksaan. Hal inilah yang dipaparkan oleh Kant dalam transendental dialektik (bagian ketiga dari putusan sistesis apriori yang ada dalam Critique of Pure Reason).

Kant menyajikan putusan sintesis-apriori dalam Critique of Pure Reason dalam tiga bagian pokok yaitu trancendental aesthethic, trancendental analytic, dan transcendental dialectic. Pada transcendental aesthethic Kant menyelidiki unsur-unsur pengetahuan yang masuk akal dengan mengacu pada suatu bentuk apriori ruang-waktu. Pada bagian ini Kant hendak menunjukkan matematika sebagai ilmu yang sempurna. Adapun bagian kedua yaitu, transcendental analytic adalah sebuah penyelidikan ke dalam pengetahuan intelektual dengan objeknya adalah dunia fisik. Bagian kedua ini pada akhirnya membuktikan bahwa fisika murni merupakan ilmu yang sempurna. 
Sedangkan bagian ketiga yaitu, yaitu transcendental dialectic, mengambil objek kajian yang melampaui pengalaman manusia, yaitu essensi Allah, manusia, dan dunia. Kant mereduksi objek-objek dari metafisika tradisional tersebut kepada "ide-ide" yang pada akhirnya sia-sia dan tidak memperoleh hasil yang pasti.

\section{Analisis Kritis}

Dari pemikiran Kant yang muncul pada Critique of Pure Reason, ada persoalan yang tersisa yaitu masalah metafisika (Amin, 2003:243). Hal ini dikarenakan sejak awal epistemologi Kant meletakkan kategori-kategori formal akal dalam jangkauan ruang waktu. Kategori harus digunakan dalam pengalaman inderawi.

Berkaitan dengan pemikiran Kant bahwa yang dapat dijangkau oleh indra hanyalah fenomena dan bukan noumena, maka pertanyaan lebih lanjut, dapatkah kepastian diperoleh dari padanya? Pada pokok persoalan ini adopsi atas pemikiran Kant ini akan memberikan peluang bagi kita untuk mengadopsi gagasan-gagasan tentang prinsip pertama. Jawaban atas semua keraguan filosofis atas prinsip-prinsip pertama akan didasarkan pada kodrat absolut dari ide mengenai "ada". Sehingga pada tataran ini perbedaan antara kesan dan kenyataan, ataupun fenomena dan noumena dapat diatasi. Karena apapun yang dimaksud dengan kenyataan noumena pastilah di dalam dirinya sendiri dapat diterapkan ide mengenai "ada".

Masih terkait dengan pokok soal kepastian, bahwa untuk memperoleh kepastian maka diperlukan evidensi. Adapun bentuk evidensi dapat bermacam-macam. Pikiran akan mengalami diri secara esensial tunduk pada evidensi ini. Evidensi ini yang akan menjamin tanggapan kognitif, entah berupa kepastian ataupun pendapat. Namun adakah kepastian absolut? Apabila digunakan perspektif Kant maka hal itu sesungguhnya merupakan permintaan yang tidak masuk akal, kepastian hanya bisa diperoleh dalam matematika maupun fisika klasik sebagai sebuah ilmu yang sempurna, sementara problem metafisika tidak akan pernah terjangkau.

Apabila dianalisis lebih lanjut hal tersebut di atas tidak saja disebabkan karena keterbatasan rasio, tetapi juga sifat pengetahuan yang analog. Pengetahuan yang ada sesungguhnya lebih bersifat 
perspektival, sehingga kepastian sebagai dukungan atas pengetahuanpun akan hadir dalam berbagai macam bentuk. Kepastian pada ilmu-ilmu alam tentu berbeda dengan ilmu sosial. Persoalannya adalah umumnya pemahaman atas kepastian ditempatkan pada kepastian fisik semata. Tetapi bukanlah kepastian fisik ini akan bermasalah ketika ditempatkan dalam relasi problemproblem kemanusiaan misalnya. Pada hubungan sosial kemanusiaan, mungkin yang lebih banyak digunakan adalah kepastian moral, atau bahkan sesungguhnya tidak ada yang disebut dengan kepastian itu sendiri. Mengapa, karena hidup manusia tidak dapat dijalani seperti hal nya rumus bangun. Hidup manusia lebih banyak dihabiskan dengan berbagai tindakan yang didasarkan pada probabilitas. Ketika kita hanya menunggu untuk sampai pada sebuah kondisi kepastian maka banyak hal akan lumpuh, dan manusia tidak akan melakukan apapun. Tindakan tidak mensyaratkan kepastian, karena hidup kita cukup dipuaskan dengan probabilitas saja. Justru dalam tindakantindakan akan semakin ditemukan kepastian tersebut.

Pada titik tertentu Immanuel Kant sepakat dengan David Hume bahwa ilmu pengetahuan tidak akan mampu mencapai kepastian. Meskipun Kant tidak menolak prinsip kausalitas sebagaimana halnya Hume. Yang menarik justru ketika Kant menemukan ada masalah dengan "metafisika" sebagai bentuk keterbatasan rasio. Melalui Rasio Murni manusia tidak mampu menjangkau pengetahuan metafisik. Oleh karena itu Kant mencoba untuk mengantisipasi persoalan tersebut dalam karyanya yaitu Critique of Practical Reason dan Critique of Judgment.

Pada Critique of Practical Reason dijelaskan bahwa begitu subjek telah melampaui pengindraan melalui rasio praktis, Kant kemudian memunculkan postulat yang membangun moralitas (Baskara, 2003:264). Postulat inilah yang menurut Kant membuat moralitas menjadi mungkin. Tiga postulat yang dimunculkan oleh Kant adalah kebebasan, keabadian jiwa, dan Allah. Penjelasannya adalah : (1) Kehendak bagi Kant bersifat melampaui dunia fenomenal, karena kehendak bersifat otonom. (2) kebajikan adalah kebahagiaan yang tertinggi. Dalam dunia fenomenal hal ini tidak selalu atau 
bahkan mustahil terjadi. Jika dalam dunia fenomenal mustahil mencapai kebahagiaan melalui kebajikan, maka kebahagiaan itu ada diluar dunia fenomenal. Akibat dari hal ini adalah munculkan keyakinan akan keabadian jiwa. (3) karena ada keyakinan bahwa kebajikan akan membawa pada kebahagiaan maka muncullah keyakinan tentang Allah. Melalui rasio praktis inilah maka manusia akan mampu mencapai metafisika.

Immanuel Kant mempertahankan pandangannya tersebut di atas dengan mengatakan bahwa sistesis apriori seperti yang telah dilakukannya di atas adalah mungkin melalui putusan atas perasaan (judgement of sentiment). Hal inilah yang disajikan oleh kant dalam Critique of Judgment. Putusan atas perasaan berbeda dengan putusan sintesis apriori, seperti yang telah Kant sebutkan pada Critique of Pure Reason. Putusan atas perasaan mengandaikan ada satu forma kosong intelek yang ditentukan oleh elemen tertentu yang diperoleh melalui proses pengindraan. Jika putusan yang diperoleh melalui sintesisapriori disebut dengan putusan penting (determining judgement) maka putusan atas perasaan itu disebut dengan putusan hasil refleksi (reflecting judgement), meliputi putusan teleologis dan putusan estetis. Putusan atas perasaan ini berasal dari luar bentuk apriori intelek, yaitu berasal dari kekuatan afektif kehendak subjek. Oleh karena itu menurut Kant, putusan yang semacam ini tidak akan memberikan putusan yang tepat, melainkan hanya memanifestasikan kemendesakkan.

Pemikiran Kant tersebut di atas sangat menarik karena Kant membuka peluang ke arah metafisika dan pengetahuan yang lebih esensial. Jika pada pemikiran Kant dalam Kritik atas rasio murni ditegaskan bahwa kita hanya dapat mengetahui objek sejauh dalam fenomen melalui persepsi inderawi, maka memang akan menjadi pertanyaan besar terkait dengan objek-objek yang tidak berfenomen. Konsep Cinta, Keabadian, Tuhan misalnya, tidak dapat dipenuhi dengan pengalaman inderawi. Jika kemudian atas dasar rasio murni disimpulkan bahwa karena tidak dapat ditangkap indra maka konsep-konsep tersebut tidak memadai, tentu ini kesimpulan yang tidak tepat. Hal ini dikarenakan tetap ada insight pengetahuan untuk hal-hal yang semacam itu. Barangkali pengetahuan yang semacam ini 
memang belum lengkap atau belum sempurna, namun bukankah pikiran manusia senantiasa terbuka dan terus berkembang secara kreatif. Pengetahuan adalah bagian dari hidup dan kehidupan manusia yang didalamnya terdapat dimensi historisitas dan sosialitas. Oleh karena itu interaksi dengan waktu, lingkungan, dan sesamanya akan memacu tumbuhnya pengetahuan secara terus menerus.

\section{SIMPULAN}

Sebagai kesimpulan akan ditegaskan bahwa pemikiran Kant dalam bidang epistemologi, yang sepenuhnya tercurah dalam karyanya yang berjudul Critique of Pure Reason ternyata masih menyisakan persoalan dalam ranah metafisika. Hal ini dikarenakan secara tegas Kant memisahkan antara fenomena dan noumena. Manusia hanya mampu menangkap fenomena saja melalui intuisi inderawi dalam ruang waktu yang kemudian dikategori dalam forma akal. Adapun noumena tidak akan pernah tersentuh. Hal ini jelas menyisakan pertanyaan terkait dengan peluang manusia untuk sampai pada pengetahuan yang essensial dan transendental.

Meskipun kemudian Kant mencoba untuk memberikan jawaban atas persoalan yang ia tinggalkan pada karyanya Critique of Pure Reason, melalui Critique of Practical Reason dan Critique of Judgement. Melalui karya yang selanjutnya tersebut Kant meletakkan problem Tuhan, keabadian jiwa dan kehendak bebas sebagai sesuatu yang dipostulatkan oleh rasio praktis dan sebagai kemendesakan ego. Namun tetap saja pada akhirnya Kant berposisi bahwa pengetahuan yang benar dan tepat adalah pengetahuan ilmiah yang diperoleh melalui kategori intelek.

Pemikiran Kant tersebut kemudian menginspirasi banyak filsuf setelahnya untuk menyajikan gagasan pemikiran tentang jangkauan pengetahuan manusia, seperti Soren Kierkegaard, Gabriel Marcel, dan yang lainnya. Di antara gagasan yang dapat digunakan untuk menyempurnakan pemikiran Kant adalah bahwa pengetahuan tidak hanya saintifik saja. Perasaan (moral dan estetika) misalnya juga akan dapat mengantarkan manusia pada pengetahuan. Nilai-nilai moral maupun estetik sesungguhnya adalah otonom, dan ketika 
seseorang sampai pada nilai tersebut, bukankah itu suatu pengetahuan juga. Namun yang perlu diingat adalah bahwa objektivitas pengalaman eksistensial seperti moral maupun estetika lebih merupakan undangan pribadi, sehingga kebebasan berperan besar disini. Jika fokus pengetahuan hanya pada yang rasio maka manusia tidak akan pernah memahami eksistensi yang Transenden. Memahami eksistensi yang transenden tidak dapat dilakukan dengan cara yang sama seperti halnya memahami objek-objek pikiran yang lain. Pengetahuan akan yang transenden hanya dapat diperoleh dengan melalui partisipasiku sebagai Subjek melalui proses eksistensi secara terus menerus.

Selain itu, manusia pun memiliki sifat multidimensional, masing-masing dimensi memiliki peran dan kemudian terlibat secara bersama-sama. Sifat pengetahuan yang analog sesungguhnya merupakan pemaknaan atas multidimensionalitas kehidupan manusia. Hal ini membawa konsekuensi pada perlunya dialog intersubjektif dan keterbukaan secara terus menerus. Pengetahuan adalah sesuatu hal yang tidak berbatas, pengetahuan manusia karenanya tidak akan pernah sampai pada ujung perjalanan melainkan hanya terus menerus diperluas cakrawalanya.

\section{DAFTAR PUSTAKA}

Amin, Miska. M., 2007, "Titik Tolak Epistemologis Filsafat Alam Semesta Immanuel Kant" dalam Jurnal Filsafat Vol.17 No.3 Desember 2007, Fakultas Filsafat UGM, Yogyakarta.

Asdi, Endang Daruni, 1995, “Imperatif kategoris dalam Filsafat Moral Immanuel Kant" dalam Jurnal Filsafat No.23 November 1995, Fakultas Filsafat UGM, Yogyakarta.

Baskara, Benny, 2003, “Interpretasi Kritisisme Immanuel Kant dalam Budaya Jawa Modern" dalam Jurnal Filsafat Jilid 35, No.3, 2003, Fakultas Filsafat UGM, Yogyakarta.

Hadi, P. Hardono, 1994, Epistemologi Filsafat Pengetahuan, Pustaka Filsafat Kanisius, Yogyakarta.

Hamlyn, D.W., "History of Epistemology", dalam Paul Edwards (ed.in chief), The Encyclopedia of Philosophy, 1967, Vol. III, hlm 6-38. 
Pranarka, A.M.W., 1987, Epistemologi Dasar Suatu Pengantar, Centre for Strategic and International Studies, Jakarta.

Taryadi, Alfons, 1988, Epistemologi Pemecahan Masalah Menurut Karl Popper, Gramedia, Jakarta.

https://plato.stanford.edu/entries/kant/. 